\title{
Citizenship education and human capabilities: lynchpin for sustainable learning environment and social justice
}

\author{
TMAROVAH
}

\begin{abstract}
The paper builds on and contributes to literature in citizenship education studies in higher education. Many studies in this field have explored the history, development and implementation of various forms of citizenship formation as an advancement of social justice. However, little has been written on how the formation of critical democratic citizens $^{2}$ links with the notion of sustainable learning environments and how it relates to social justice. Studies by McKinney (2007); Waghid (2007; 2009), Lange (2012); and Leibowitz, Swartz, Bozalek, Carolissen, Nicholls \&Rohleder(2012) are among those on citizen formation in the South African higher education context. Thisconceptual paper argues that the formation of critical democratic citizens through higher education relates not only to social justice, but also to the advancement of sustainable learning environments (SLEs) beyond physical spaces. The paper explores the normative value of a democratic education theory, Marion Young's (1990) theory of justice and the politics of difference, and human development principles in advancing citizenship education. These foster both sustainable learning environments and social justice. A democratic education theory lays the foundation for an inclusive and deliberative form of education, while a theory of justice and politics of difference advances better justice and an environment that is non-oppressive. Human development principles set the tone for a sustainable human development, which becomes a framework through which asustainable learning environment is built in pursuit of social justice. Drawing on a Capabilities Approach framework and the philosophy of Ubuntu, with emphasis on substantive freedoms, opportunities, and the thriving of the common good, the paper illustrates how citizenship education advances a conception of sustainable learning environments and social justices not necessarily limited to physical spaces, distributive justice or economic motives, but inclusive of institutional arrangements, policy issues and relational justice.
\end{abstract}

Key words: sustainable learning environments, social justice, citizenship education, Ubuntu, human capabilities

\section{Overview}

I will start by discussing various definitions assigned to the key terms in this paper: sustainability, learning environment, sustainable learning environment and social justice. This conceptual understanding will be used to explicate how citizenship education leading to the formation of critical democratic citizensthrough higher education provides a significant

1 Tendayi Marovah is a postgraduate student in the Centre for Higher Education and Capabilities Research (CHECaR) at the University of the Free State. Email: marovaht@gmail.com 
leverage towards linking sustainable learning environments and social justice. A democratic theory provided by Amy Gutmann (1987), Iris Marion Young's (1990) theory of social justice and the politics of difference, human development principles, a capability approach, as well as the philosophy of Ubuntu, will be used to provide a framework through which citizenship education and human capabilities play a role in this matrix. I will put emphasis on the argument that a capability approach provides a more pronounced nexus between SLEs and social justice.

\section{Sustainability}

It is with the understanding that concepts around sustainability - including sustainable learning environments - take their cue from millennium development goals that were later translated into sustainable development goals. Stallmann (2010) suggests that sustainability should be understood as more expansive and multi-layered. As such it is applicable in many areas of sustainability including but not limited to development, environment, learning environments and policy formulation. While this paper does not focus on SLE policy, it looks at how SLE intersects with social justice. I acknowledge that there are many definitions of sustainability sharing the same characteristics, such as conservation of resources, caring for the environment as well as integration equity. Based on Stallman's argument, I infer that no single definition can be advanced as fitting all situations in sustainability, making it necessary for specific definitions to be created to ensurean understanding within specific contexts or organisations. The United Nations ${ }^{3}$ (1987, p.54) defines sustainability in development terms as addressing our current challenges without "borrowing" from future generations' potential to do the same. While this definition is inclined to the ecological paradigm with its emphasis on resource utilisation, the Sustainable Development Gateway (2010) ascertains that sustainability has shifted from an ecological paradigm to one that includes the economic and social concerns in the Brundtland report. The continued variations in the definitions are also noted in how the Ministry for the Environment (MfE) of New Zealand (2009, p.3) describes a sustainably built environment as "one which takes into account the needs of future generations, ecological health, public participation and equity." The addition of public participation gives emphasis to the significance of a process which promotes relational justice and empowers societies through deliberations. Drawing on this assertion, I advance the notion that the creation of stronger, healthier and more equitable communities can be considered as central to sustainability in any context, making it imperative to focus any programme towards sustainability to this end. UNESCO (1997, p.31) explains that sustainability calls for a dynamic balance among various factors, "including social, cultural and economic requirements of mankind and the imperative need to safeguard the natural environment of which humanity is part." What is sought, in this case, is the well-being of all people. Before exploring how SLE is defined, I will first dwell on the general definition of learning environments.

This is derived from the Brundtland Report of the World Commission on Environment and Development of 1997. 


\section{Learning environments}

Said, Rogayah \& Hafizah (2009) ascertain that learningenvironments can be viewed through many perspectives. Whilst generally learning environments allude to place and space - a school, a classroom or a library - Saidet al.argue that learning environments constitute more than student-teacher interaction, teaching and learning activities, good physical structures and facilities provided by an institution of learning. Bloom, cited in Saidet al. (2009) describes learning environments as circumstances - endogenous and exogenous, which may impede or promote capacities of learners in the process of learning. From these definitions, I conceive the range of learning environments to be expansive, ranging from the most immediate social interactions to the more remote cultural and institutional forces. Thus, when learning environments are assessed, the scope of the assessment should be inclusive of the varied contexts and range of possible forces, conditions, structures and interactions that may ensue in the context. Said et al. (2009, p.12) summarise learning environments as "an interactive network of forces within the teaching and learning activities that influences students' learning outcomes." In other words, it does not necessarily need to be a physical place; it can be virtual, online or remote. While I agree with the assertion that the concept of learning environment has been well recognised in the educational literature, the focus has been limited to the physical environment and the classroom environment, instead of being inclusive of other interactive forces and institutional arrangements that influence the students' learning outcomes. I will now turn to the definition of Sustainable Learning environments (SLE).

\section{Sustainable learning environments}

Many definitions proffered on SLEs allude to a framework more inclined towards the preservation of the natural environment through efficient use of natural resources whilst at the same time ensuring an advancement of the well-being and security of humanity (Stallmann, 2010; UN, 1987; Sustainable Development Gateway, 2010; Salama \& Adams, 2003). The major focus is on environments that are resource efficient, provide good indoor environmental quality and protect the wider environment. In some instances, these scholars agree that learning environments may include all those spaces where teaching and learning take place, but they maintain that SLE "may also be read as sustainable, green or high performance schools" (Stallmann 2012, p.1). To them, the need for an SLE policy has a number of drivers centred on the need to conserve resources, such as energy and water as well as concerns for global warming and community environmental concerns. While these form an integral part of the SLE, viewing them as an end in themselves will be problematic for limiting the focus on the ecological implications, rather than putting human beings at the centre of sustainability concerns. I argue that SLE should aim at enabling learners towards realising their freedoms and opportunities to choose to be and/or do what they value, while simultaneously making meaningful a contribution towards the flourishing of their communities. Therefore, I borrow the definition of SLE offered by MfE (2009, p.vii) which emphasises that "SLE should lead to the creation and strengthening of relationships and communities by focusing on the process of engagement as well as the outcomes." 
Drawing on Pirage (1994), $\mathrm{ECE}^{4}$ (1996) and PNWPPRC ${ }^{5}(1999)$, I argue that the concept of SLE encompasses more than physical, economic or ecological aspects. It embraces social, cultural, behavioural and political dimensions. In this regard, adopting principles of sustainability as a comprehensive approach is essential if a society is to seek more meaningful solutions addressing inequalities, poverty and social injustices plaguing our society. On this note, I will define the term "social justice" and relate it to the notion of SLE. To this end, I will draw on the theory of social justice and the politics of differences.

\section{Social justice}

Young (1990) asserts that justice should be more expansive to include institutional arrangements necessary for the advancement of the well-being of the whole society at the same promoting public deliberations and individual rights. This is useful for motivating a conception of a curriculum which does not centre on the distributive aspects of social justice only. I argue that it is these institutional conditions which may hinder the full capacities of individuals or groups in the process of deliberation even in well-intended democracies. When social justice in education is perceived from this angle, it has an insightful demeanour on SLEs stretching beyond issues of access and allocation of resources to education which is not limited to distributive justice.

Young's theory is significant in this paper for exposing varied forms of injustices which are subtly embedded in everyday societal practices through different arrangements, which may be perpetuated in education. Drawing from Walker's (2010) argument that societal arrangements may inhibit promising and authentic human capabilities, I advance Young's theory in critically analysing possible constrains in not only economic and social arrangements but also political in the formation of democratic citizens through citizenship education. Such an analysis is imperative for two important reasons: Firstly, I seek to advance the republican idea of citizenship which calls upon the active participation of every citizen on the basis of equality. Secondly, the form of democratic practice I seek to draw from the democratic education theory is that of deliberative democracy, with its emphasis on the ideals of inclusion, political equality and reasonableness (Young, 2000). The five faces of oppression ${ }^{6}$ envisaged in Young's theory promote injustice in that they incapacitate various groups and also promote subjugation by groups privileged through power. It is important to note that Young stresses that oppression is not experienced by all in the same way or to the same degree. However what is important is that all suffer some form of restriction to freedoms, opportunities and choices to cultivate and secure their potentials to deliberate or participate as equal citizens of a polity. What it means is that one's capacity to deliberate may suffer from more than one form of oppression at the same time. For example, one can be both exploited and powerless to be unable to participate in a deliberation. Young (2000) criticises existent

4 An Economic Commission for Europe 1996 paper on Guidelines on Sustainable Human Settlements Planning and Management

5 Pacific Northwest Pollution Prevention Resource Centre 1999 Topical Reports on Sustainable Design for Schools

6 These are the five forms of oppression- exploitation, marginalisation, powerlessness, cultural imperialism and violence - they are not necessarily independent of one another. 
democracies for their exclusionary tendencies advanced by powerful elitist groups which enjoy more power in decision making whilst excluding weaker groups in public deliberations. I will therefore argue that the democratic education theory is an ideal theory which must be integrated in practice, with knowledge of the subtle ways in which deliberation may be inhibited through any of the five faces of oppression.

The major weakness in Young's theory is that whilst it is elaborate in exposing how social justice and democratic values can be inhibited through institutional conditions, it does not give tangible suggestions on how this can be avoided, besides through an inclusive approach. Furthermore, Young does not apply this theory to the field of education. However, we can surmise that:

"...her strategies would include, minimally, curricula that reflect the multicultural, multinational, and multilingual nature of society, programmes that raise awareness of how racism, sexism and homophobia manifest themselves, decision making structures that ensure that the voices of parents, teachers and community leaders from disadvantaged groups are affirmatively incorporated." (Eisenberg, 2006, p.21)

We can thus charge citizenship education in a post conflict Africa with the task of securing the opportunities of the oppressed through a critical and democratic curricular which is conscious of the potential dangers to which democratic education is exposed through institutional arrangements. I now turn to the role of education in advancing social justice, which is in essence a coordinate of SLE.

UNESCO (1997), commenting on sustainability hints that moving towards the goal of sustainability requires fundamental changes in human behaviour and attitudes. Progress in this direction is critically dependent on education and public awareness. In this regard, the type of education I advance is democratic education.If this is to be achieved, the type of citizenship education perceived should be undertaken in SLE. Mayor (1997) argues thatthis education "reaches out to all members of the society through new modalities and new technologies in order to provide lifelong learning opportunities for all." Using a democratic theory of education, I explain how citizenship education may advance SLEs promoting social justice.

\section{Democratic education theory, social justice and SLEs}

Gutmann (1987) emphasises the need to idealise education as a democratic process. She notes that, for a society to reproduce ${ }^{7}$ (not replicate $^{8}$ ) itself, it must be non-repressive. To her, democratic education and democracy cannot thrive in a repressive context. Thus, pedagogical practices should aim to teach the skills of reasoned deliberation to a society of free and equal citizens. Gutmann's theory on the formation of democratic citizens motivates the need to ascertain SLEs. Gutmann (1987) argues for the advancement of capabilities necessary for political engagement in a democratic polity through education. The question is to what extent $\mathrm{HE}$ embraces this role, given its inclinations towards the human capital school of

$7 \quad$ Reproducing means continually exploring ways to meet the changes occurring in the development of new needs on the part of human beings, and new resources for satisfying these needs.

Replicating implies an uncritical repetition of traditions as a way of solving challenges.

TD, 9(3), Spec. ed., December 2013, pp. 593-607. 
thought and the emphasis on ecological and structural paradigms when it comes to considering SLEs. Drawing on Gutmann's arguments, I concede that the success of the formation of critical democratic citizens lies in the distribution of power in making decisions about educational policies which in itself constitute sustainable leadership.

The democratic education theory believes in shared authority among all sections of the society. Gutmann (2003) argues that children must be educated for individual freedom in a context where individually or collectively people should have the freedom, opportunities and choice to lead a good life and negotiate what they value as a society. Without these, it may be impossible to have education enhancing individual freedom, as political liberties are at the heart of any democratic state. Without which, tyranny is most likely to prevail in education as in society. Therefore, democratic education is by implication education in anSLE - a state in which democracy prevails or it moves towards a more democratic form. From these arguments, democratic education in non-SLEs may be impossible. In tandem with the spirit of sustainability, I draw on Dewey's words that "the very idea of democracy must be continually explored afresh to meet the changes that are going on in the development of new needs on the part of human beings and new resources for satisfying these needs" (Watkins, 2008 , p.72).Democracy involves the participation and plural values of many ${ }^{9}$. It is used to describe a situation where the participation of the majority is through what Sen (2009) calls "public reasoning". Therefore, the idea that gives exclusive authority to some sections of the society defeats the notion of "public deliberations". A theory of democratic education is thus relevant in advancing ideals on SLEs and social justice inHE in the formation of critical democratic citizens.

Citizenship education inspired by the democratic education theory prepares students for the critical role of active participation in the society in which they should be ready to obey and to govern (White 2013). It also provides some insights into questions on how citizens should be educated and by whom, the content of education, its distribution, and the distribution of educational authority - allof which are necessary for the development of a curriculum for citizenship education (Gutmann, 1987). Furthermore, the democratic theory ideals resonate with the spirit of sustainability through a republican view of citizenship education of deliberative democracy among free and equal individuals, which entails that citizens and their accountable representatives owe one another justifications for the laws that collectively bind them (Lawson \&Scott, 2002). Gutmann (1987, p.xiii) adds that "the willingness to deliberate about mutually binding matters distinguishes democratic citizens from self-interested citizens, who argue merely to advance their own interests." Therefore, a necessary condition of an adequate civic education is to cultivate the skills and virtues of deliberative citizenship, which are essential for a fuller life in a democratic state. From this perspective, HE sets the tone for SLEs useful for democratic politics, simultaneously reinforcing an ideal of education, which abrogates any attempt to subvert social justice. Drawing from Gutmann, I argue that a democratic education should seek to secure human capabilities that is, their freedom, choices and opportunities to participate as critical democratic citizens in making decisions that affect them and that of future citizens. In this case, $\mathrm{HE}$ for critical democratic citizenship is distinguished from HE driven by other motives, such as profit-making by its distinctive SLEs. 
Lastly, I explain that a symbiotic relationship between SLEs and social justice should be envisaged if a democratic education theory takes centre stage. Walker (2010, p.221) argues that "changes in higher education might influence society as much as society in turn shapes higher education." Thus, we need SLEs to further socially just or critical democratic citizens, in as much as we need socially just or democratic citizens to further SLEs. However, the assumptions at the heart of this theory make it ideal, because it is hard - if not impossible to come up with a purely democratic society in which social justice is exercised. Yet, it is necessary as a standard towards which we may work. I now turn to human development principles and how they contribute to the framing of a higher education curriculum advancing both SLEs and social justice.

\section{Human development principles, social justice and SLEs}

Democracy, social justice and the CA all have a common focus of sustainable human development (HD). I advance HD as defined by the UNDP (1990) and notfrom the human capital perspective, which focuses on health and education as inputs to economic production. According to the UNDP, human development is:

about creating an environment in which people can develop their full potential and lead
productive, creative lives in accord with their needs and interests. People are the real
wealth of nations. Development is thus about expanding the choices people have to lead
lives that they value. The emphasis is on cultivating an environment or a context in
which human beings realise their maximum possibilities and also realise useful or
beneficial, and inventive lives in alignment with their valued necessities and well-
beings." (1990, p.1)

This definition marks a shift from the commonly held view that there is a close link between a country's economic growth and well-being / quality of life. This is mainly because, as Sen (1999) argues, a country's Gross Domestic Product does not tell us how the wealth so gained is distributed across the population, nor does it give insights into the quality of the growth achieved. According to UNDP (1990) this notion, propounded and developed by Mahbub ul Haq and Amartya Sen, recognises human beings as the real wealth of the universe. Therefore, HD should not be measured by how much material gain is achieved in the process of human activity, but rather by how much value has been added towards improving human potentials, choices or freedoms to be or do that which they perceive as valuable. This position is important because it contrasts to the previously dominant view where economic gains were placed at the centre of measuring human development. Thus, sustainability fostering human development should be socially, economically and politically just, as such that SLEs mapping should transcend cost effective or economic standards removed from improving the wellbeing of people.

Understanding HD in the above terms augurs well with SLEs advancing social justice. UNDP Belize (2012) concludes that "human development is the development of the people for the people and by the people." Drawing on the principles of HD, it is then important that purposes of $\mathrm{HE}$ and even curriculum innovations put people at the centre of their innovations not only as skilled manpower but as the wealth of the nation. Sen (1999) argues that HD is concerned with the basic development idea of advancing the richness of human life rather than the economy in which human beings live, which is only part of it. This resonates with 
Mahbub ul Haq's notion on the same where human choices, freedoms and opportunities are at the heart of development (UNDP 1990). Thus, the objective of development in Mahbub ul Haq's words is "to create an enabling environment for people to enjoy long, healthy and creative lives." This is a vision on enlarging people's choices and freedoms to pursue what they value to be or to do is empowering and therefore in line with advancing social justice.

The thrust is on constantly providing for the various contexts that give people the zest to move on rather than to be stagnant; the power to explore new possibilities rather than continue with traditional systems, which tend to stifle creativity and divergent thinking and lead to path of dependency. The UNDP definition thus foregrounds critical thinking, innovation and productive intellectualism that are not measured in what Nussbaum (2006) terms "profit making motivations." Rather by emphasising the centrality of human beings as the real wealth, it arouses a consciousness that recognises that before we are anything, we are human beings, - whichis an underlying principle in the philosophy of Ubuntu. I will explore this in detail in the next section. Furthermore, it should be noted that economic growth will not necessarily lead to people's well-being. Human development reports (UNDP, 1990) provides evidence that there are countries with strong economies that still have many people without the basic capabilities needed to live a healthy life as prescribed by the human development framework. Walker's (2010) argument to this effect need to be emphasised:

"If human capital and economic growth have failed to provide both for economic and buman security, then serious questions ought now to be raised about the appropriateness and sustainability of this as a continuing higher policy direction; we need rather to rebalance higher education goals in the direction of a more expansive public good, and the formation of graduates as rich human beings." (p.221)

Drawing on this argument, it becomes imperative to reimagine the role of $\mathrm{HE}$ as not only limited to economic terms or employability, but to expand and secure the well-being of individuals through the formation of critical democratic citizens. While economic structures are important as an aspect of plural well-being, they should not be advanced at the expense of the socio-political role of development as a participatory and dynamic process. I therefore understand the HD principles as foregrounding SLEs not only in economic terms, but also advancing social justice. I now advance the philosophy of Ubuntu as an integral part in the process of conceptualising the formation of critical democratic citizens in SLEs simultaneously advancing social justice.

\section{Ubuntu, ${ }^{10}$ social justice and SLEs}

Because of the value placed on Ubuntu in Africa, I use this philosophy as leverage in claiming capabilities necessary for the formation of critical democratic citizens. The philosophy has not been widely used as an application to the advancement of the formation of critical democratic citizens. Drawing from several scholars on Ubuntu (Broodryk, 2002; Swanson, 2007; Venter, 2004; Waghid, 2004; and Waghid, 2013), I argue that Ubuntu is not just an idea, but a way of life of African origin. It embodies the world view of Africanness and therefore is essential 
in discussing issues in respect of the formation of democratic citizens, SLEs as well as social justice in an African context. I note that this world view has both strengths and weaknesses in an effort to advance socially just societies and SLEs.

From the arguments advanced by Broodryk (2010), Ubuntu can be used to make claims for the formation of critical democratic citizens. For example, "Ubuntu philosophy displays tolerance, awareness of what is just and unjust, what is humane and inhumane; an awareness of the distinction between kindness and cruelty, between harmony and disharmony..." (Broodryk, 2010, p.47). This testifies that Africans are not alien to the notion of citizenship and social justice. It underscores the significance of consensus and the well-being of the community, rather than the individual - unlike some of the Western liberal notions of citizenship. Whilst on the surface the claims made by Ubuntu appear to be universal values, it is the emphasis given to these values which exhibit an interdependence of humanity as well as the influence of indigenous knowledge systems which makes it powerful knowledge necessary in the formation of critical democratic citizens (Venter, 2004; Swanson, 2007). The philosophy therefore separates African world view from other worldviews in more than one sense making it imperative for $\mathrm{HE}$ teaching to be framed within an African world view (Waghid, 2004). This is a sure way of making African HE responsive to the needs of Africa without alienation from the rest of humanity thereby expanding SLEs and the ethos of social justice.

Far from the influence of human capital and profit-making motive, development in the African world view seem to resonate with the notion of development according to the human development principles already discussed. It seeks to advance the common good by configuring all activities around human beings and what they commonly value. Thus, in advancing Ubuntuas an important philosophy in the formation of critical democratic citizens, I view a human capital orientation as alien to the African system and therefore unsustainable for a curriculum that seeks to advance the well-being of humanity.

Letseka (2012, p.44) defends Ubuntu on the basis of its spirit which emphasises "group solidarity, comparison, respect and human dignity." This group solidarity is not to be confused with categorising the community into "us" and "them", but based on the notion which can be summed up as, I am because we are, and since we are, therefore I am (Waghid, 2004). The significance placed on this philosophy for example in the South African context is seen in its presence in policy documents such as the White Paper (Department of Education, 1997) and even the National Constitution (Swanson, 2007). From the above evidence, while the philosophy has been used at national level for the purposes of national integration, I submit that the promotion of Ubuntu through education is critical for the formation of critical democratic citizens. However, I would concur with the fears expressed by Takupiwa, Mudhovozi, Zirima and Kasayira (2011) on the close association of the philosophy of Ubuntu with the culture of obedience for the youths. This obedience may be problematic when it turns into unquestioning obedience. Takupiwa et al (2011, p.353) deplore that "youth obedience has been manipulated to exploit youths who are, in most cases, vulnerable due to their weak economic status." This economic status will thus become an opportunity of oppression through either exploitation or powerlessness on the part of the youths.

Once Ubuntu is accepted as a philosophy of life, it can as well be accepted as a philosophy of education. Venter (2004, p.149) argues that the two can keep together, "because a philosophy of life helps to identify the goals and purposes that a particular society holds dear." From the African world view, Venter identifies a number of values important for the existence of 
mankind, and therefore recognises them as important for an African philosophy of education on the basis that education is essence a preparation for human life. Moreover, educating graduates for citizenship by passing on values and virtues perceived to be held by the society is among the goals of HE (Ahier et al, 2003). Therefore, HE can play an important role in transferring the African philosophy of life for the formation of critical democratic citizens. Waghid (2004) argues that:

\section{African philosophy can contribute to the transformation of educational discourse in South Africa, empowering communities to participate in their own educational development, since it respects diversity, acknowledges lived experience and challenges the hegemony of Western Eurocentric forms of universal knowledge (p.128)}

This is in line with the principles of HD in which development should be of the by the people for the people.

In the preceding sections I analysed major theoretical perspectives and frameworks that I use in explaining how the formation of critical democratic citizens relates with SLEs and the advancement of social justice. My analysis focused on the conceptual analysis of the theories and frameworks placing emphasis on how they form a firm foundation in claiming capabilities necessary in advancing SLEs and to expand social justice. I now propose that a capabilities approach (CA) through its major concepts, such as capabilities, functionings, agency and conversion factors, provides a clearer alternative for both theory and practice of $\mathrm{HE}$ and citizenship education leading to the formation of critical democratic citizens in SLEs. While the CA does not explain the causes of educational policy inadequacies, it provides a tool with which to conceptualise and evaluate them (Unterhalter, Vaughan \&Walker, 2007). In addition, I concur with Walker's (2010) argument that foregrounding the capabilities approach in curriculum issues directs us towards a holistic approach in the assessment of contexts which inhibit or enable individuals' freedoms, opportunities and choices to make decisions to be or to do what they value in life.

\section{Capabilities approach, social justice and SLEs}

The CA is a theoretical framework advancing two normative claims: freedom to achieve wellbeing as being of primary moral importance, and for this freedom to achieve well-being being understood in terms of capabilities (Sen, 1999; Nussbaum, 2000). Amartya Sen and Martha Nussbaum pioneered the approach which is now being further developed and applied by a number of scholars, including Elaine Unterhalter, Melanie Walker, Ingrid Robeyns, among others. Considering that the fundamental idea of the capability approach is that social arrangements should aim to expand people's capabilities - their freedom to promote or achieve 'functionings' I argue that its emphasis on advancing freedom and choices is of significance not only in the curriculum that seeks the formation of a particular type of citizens- democratic but also in advancing social justice and SLEs. Democracy and social justice is about freedom and choices but these have to be based on weighed reasons. Capabilities are "the alternative combination of functionings that are feasible for [a person] to achieve' well-being; they are 'the substantive freedom' a person has 'to lead the kind of life he or she has reason to value" (Sen, 1999, p. 87). Instead of aiming to equalise resources, Sen argues that equality should be aimed at increasing freedoms and opportunities of individuals to pursue and to achieve their well-being. 
The CA provides a broader platform for thinking about social justice and higher education that involves expanding people's capabilities through the formation of critical democratic citizens. Resonating with the theory of justice and the politics of difference, I advance the $\mathrm{CA}$ as a tool to investigate how social and political context sets SLEs for individual freedoms in the formation of critical democratic citizens. Unterhalter, Vaughan and Walker, (2007) argue that education should be used to equalise people's choices, freedoms and opportunities to do and to be what they value. In this way, the capability approach provides a framework which is sensitive to diverse social settings and groups. From this analysis, the importance of freedom and choice as SLEs is important in the process of the formation of the critical dimension in citizens. At the same time Lange (2012, p.3) sees citizenship as "the enacting of human freedom (action) exercised in relation to interrelated spheres: the public sphere where citizens act in concert through deliberation and the common world." In both instances capabilities are important in cultivating well-being and social justice. Closely linked to capabilities are functionings, which I will interrogate next.

Sen (1999, p.75) defines functionings as "the various things a person may value doing or being" While a capability is a potential functioning, a function is what one actually manages to achieve or do - and the list of functionings is endless." Walker (2006) argues that it is the transformation of one's opportunities, freedoms and choices to do and to be what one values into concrete achievements like "being well-nourished, having shelter and access to clean water and being physically safe, or more complex functioning like being well educated, having paid professional work, being respected, taking part in discussions with your peers, being scientifically literate, and so on" (p.128). From these examples, it can be argued that the realisation of the function follows the availability of an opportunity and the freedom to choose to convert the opportunity into reality. In democratic citizenship, it can be inferred that taking part in a deliberation is secured by the availability of the opportunity to do so which unless secured by the necessary freedoms and opportunities may not be realised. For this reason, all forms of oppression as espoused by the theory of justice and the politics of difference should be eliminated (Young, 1990). The form of education advanced as guaranteeing this is derived from the democratic education theory in SLEs. Drawing on this analysis, I argue that $\mathrm{HE}$ should be interested not only in whether a student has the potential and freedom to be critical, but also about their learning environment - social, political and economic. Therefore, while HE policies and college syllabi may reflect genuine capabilities (potential freedoms and opportunities) for the formation of critical democratic citizens, it is the learning environment in which this is undertaken that must be the standard of measure of a successful realisation of a critical democratic citizen. Sen (1993) argues that the quality of life depends on the "functionings" that are feasible to achieve in the contexts within which we are located. Nixon (2011, p.70) argues that "higher education not only contributes greatly to our achieved 'functionings', but also provides an institutional space to exercise our freedom our capability - to choose between alternative combinations of 'functionings." The connection between capabilities and functionings is unquestionable, but also depends on other factors, such as agency, which I will discuss next.

I draw on the arguments raised by Bonvin \&Thelen (2003), Nixon (2011), Nussbaum (2000) and Sen (1999) to explicate the concept of agency. Borrowing from Sen (1999) I advance the notion that it is the stimulation and commitment of the individual learner (agency) which makes 'functionings' 'important in securing human freedoms, choices and opportunities to do and to be what they value. In other words, the will to be or not to be will make a difference in 
the way a student advances or regresses. For this reason, Nussbaum (2000) argues that citizens must be left to determine what they make of the capabilities that are granted them. At the same time, what individuals make of their capabilities will depend on a number of factors. Walker (2006, p.36) argues that "crucially, functionings depend on individual circumstances, the relations a person has with others, and social conditions and contexts within which potential options (freedom) can be achieved." Sen (1999) and Bonvin \&Thelen (2003) thus argue that Individual agency is determined by social and economic arrangements, political and civil rights. These will either promote or deter our agency. Thus, individual agency is in turn dependent on social arrangements which must secure individual freedoms, opportunities and freedoms to achieve well-being (Sen, 1999). What we do speaks of our agency, yet our agency limits what we do. In Nixon's (2011, p.103) words, “our actions define our agency, but also define the limits of our agency, given that we are creatures of time (bound, that is, both to 'the living and the dead').Individual functionings therefore are influenced by a person's relative advantages in society and enhanced by enabling public and policy environments." The implications of this concept to citizenship education centres mostly on how the potential to be critical by individual students may be upset or promoted by the context or learning environment in which they operate.

The CA takes cognisance of this fact and advances the notion of social, political and economic arrangements, which Sen (1999) calls "conversion factors", as significantly contributing to the realisation of functionings. Functionings to achieve certain beings and doings are influenced by three types of conversion factors: firstly, personal characteristics (e.g. physical condition, sex, reading skills) - ifsomeone has difficulty in reading and writing (illiteracy), the idea of freedom to choose a leader as an equal citizen is not applicable within the context of the secret ballot. The person will need to be assisted to vote, even though the assistance rendered itself is a conversion factor enhancing the exercise of the right to vote. Secondly, social characteristics (e.g. public policies, social norms and practises), such as obedience and respect for elders, may be used to suppress dissenting voices of youths or to suppress women in a patriarchy. Thirdly is environmental characteristics (e.g. climate, infrastructure, institutions, public goods) (Robeyns, 2003). Therefore, the concept of conversion factor is important in highlighting the need to know more about the persons and the circumstances in which the formation of democratic citizens is sought.

\section{Conclusion}

This conceptual paper advances expansive definitions of sustainability, learning environments, sustainable learning environments as well as social justice. The conceptualisation of these terms brings out a link between social justice and SLEs. Drawing from a democratic education theory, a theory of social justice and politics of difference, human development principles, the philosophy of Ubuntu and the capability approach, the paper theorises the nexus between social justice and SLEs. The aim is to operationalise these concepts in enhancing learning. While the paper idealises citizenship education as a way of forming critical democratic citizens, it does not overlook the possible shortcomings of advancing SLEs grounded on social justice. The capability approach is foregrounded as a possible strategy through which the agenda for social justice and the creation of SLEs could be advanced. 


\section{References}

Ahier, J., Beck, J. \& Moore, R. (2003) Graduate citizen? Issues of citizenship and higher education, RoutledgeFalmer, London/New York

Bonvin, J.M. \&Thelen, L. (2003) Deliberative Democracy and Capabilities, the Impact and Significance of Capability for Voice, paper presented at the Third Conference on Capabilities, Pavia, 7-9 September

Broodryk, J. (2002) Ubuntu: Life lessons from Africa, Ubuntu School of Philosophy, Tshwane

Economic Commission for Europe (ECE) (1996) Guidelines on Sustainable Human Settlements, Planning and Management, United Nations Publications, New York/Geneva

Department of Education (1997) White Paper 3: A Programme for the Transformation on Higher Education. 1997. Government Gazette. Pretoria: South Africa.

Eisenberg, A. (2006) Education and the Politics of Difference: Iris Young and the politics of education, in Educational Philosophy and Theory, 38 (1), pp.7-22

Gutmann, A. (1987) Democratic education, Princeton University Press,New Jersey

Gutmann, A. (2003) The authority and responsibility to educate, in Curren, R.(ed.) (2003) A Companion to the Philosophy of Education, Blackwell Publishing, Oxford

Lange, L. (2012) Understanding and action: Thinking with Arendt about democratic education, in Perspectives in Education, 30(4), pp.1-8

Leibowitz, B., Swartz, L.,Bozalek, V.,Carolissen, R., Nicholls, L. \&Rohleder, P. (eds.)(2012) Community, Self and Identity: Educating South African University Students for Citizenship, Cape Town: Human Sciences Resource Council

Letseka, M. (2012) Indefense of Ubuntu, studies in Philosophy of education, vol. 31, pp.47-60

Mayor, F. (1997) Preface in United Nations Educational, Scientific And Cultural Organisation (UNESCO) Educating for a sustainable future: A transdisciplinary vision for concerted action, EPD-97/CONF.401/CLD.1.

McKinney, C. (2007) Caught between the "old" and the "new"?: Talking about "race" in a postapartheid university classroom, in Race Ethnicity and Education, 10:2, pp.215-231

Ministry for the Environment (2009). Retbinking our built environments: Towards asustainable future. Retrieved October 2013, from http://www.mfe.govt.nz/publications/susdev/rethinking-our-built-environment/

Nixon, J. (2011) Higher Education and the Public Good: Imagining the University, Continuum International Publishing Group,London/New York

Nussbaum, M.C. (2000)Women and Human Development: The capability Approach, Cambridge University Press, Cambridge

Nussbaum, M.C. (2006) Education and Democratic Citizenship: Capabilities and Quality Education, in Journal of Human Development, 7:3, pp.385-395

Nussbaum, M.C. (2011) Teaching Patriotism: Love and Critical Freedom, for a conference on Understanding Education in the United States: Its Legal and Social Implications, University of Chicago Law School, 17-18June 2011.

TD, 9(3), Spec. ed., December 2013, pp. 593-607. 
Pirage, D. (ed.) (1994) Sustainability as an Evolving Process, inFutures, vol. 26

Pacific Northwest Pollution Prevention Resource Center (PNWPPRC) (1999) Topical Reports:Sustainable Design for Schools, PNWPPRC Publications, Seattle, WA

Robeyns, I. (2003) Sen's Capability Approach and Gender Inequality: Selecting Relevant Capabilities, in Feminist Economics, 9:2, pp.61-92

Said, N.M., Rogayah, J.\& Hafizah, R. (2009) A study of learning environments in the Kulliyah (faculty) of Nursing, International Islamic University Malaysia, in Malaysian journal of medical science, $16: 4$

Salama, A. \& Adams, W.G. (2003) Sustainable Learning Environments: Rethinking the MissingDimensions, inAl Azhar University Engineering Journal-AUEJ, vol. 7, Special Issue, ISSN-11106406

Scott, D. \& Lawson, H. (2002) Citizenship Education and the Curriculum International Perspectives on Curriculum Studies, Abelex Publishing, London

Sen, A. (1993) Capability and Well Being, In Nussbaum, M.\& Sen, A. (eds.), The Quality of Life, Clarendon Press, Oxford

Sen, A. (1999) Development as Freedom, Oxford University Press, New York

Sen, A. (2006) Identity and Violence: The Illusion of Destiny, Norton and Company, New York

Sen, A.(2009) The Idea of Justice, Penguin, London

Swanson, D.M. (2007) Ubuntu: An African contribution to (re)search for/with a "bumble" togetherness, in Journal of contemporary issues in education, 2 (2), pp.53-67

Stallmann, M. (2010) Sustainable Learning Environments: The Issues and Potential Policy Responses, master's dissertation, Lincoln University

Takupiwa, N., Mudhovozi, P., Zirima, H. \&Kasayira, J (2011) Youth culture: A melting pot in Zimbabwe, in Journal of Sustainable Development in Africa, 13(2), pp.352-365

The Sustainable Development Gateway (2010) Introduction to Sustainable Development, retrieved 29 September 2013 from http://sdgateway.neUintrosd/definitions.htm

United Nations (1987) Brundtland Report of the World Commission on Environment andDevelopment, New York, United Nations

United Nations Development Programme (UNDP) (2012) Belize Human Development Report, retrieved on 23 March 2013 fromhttp://www.bz.undp.org/belize/en/home.html

United Nations Development Programme (UNDP) (1990) Human Development Report, retrieved on 23 March 2013 from http://www.undp.org/content/undp/en/home.html

United Nations Educational, Scientific and Cultural Organisation (UNESCO) (1997) Educating for a sustainable future: A transdisciplinary vision for concerted action, EPD97/CONF.401/CLD.1

Unterhalter, E.,Vaughan,R. \& Walker,M. (2007) The Capability Approach and Education in Prospero, based on a briefing written by the authors for the Human Development and Capability Association(HDCA),November 2007 
Venter, E. (2004) The notion of Ubuntu and communalism in African educational discourse, in Studies in Philosophy and Education, KuwerAcademic Publishers, The Netherlands

Waghid, Y. (2004) Revisiting the African - AfricanaPhilosophy of Education Debate: Implications for University Teaching, in Journal of Education, No 34

Waghid, Y. (2007) Educating for Democratic Citizenship and Cosmopolitanism, in South African Journal for Higher Education, 21:5, pp.584-595

Waghid, Y. (2009) Education for Responsible Citizenship, in Perspectives in Education, Volume 27:1, pp. $85-90$

Waghid, Y. (2013) African Philosophy of Education Reconsidered: On Being Human, Routledge,Oxon, New York

Walker, M. (2006) Higher Education Pedagogies: A Capabilities Approach, Open University Press,Berkshire

Walker, M. (2010) Pedagogy for Rich Human Beingnessin Global Times, in Unterhalter, E. \&Carpentier, V. (eds.), Global Inequalities and Higher Education: Whose Interests Are We Serving? Palgrave McMillian, Hampshire

Watkins, D. (2008) Conceptualizing Democracy in a Global Era, Eisenhower, Proquest LLC

White, M. (2013) Higher Education and Problems of Citizenship Formation. In Journal of Philosophy of Education, 47:1,pp.112-126

Young, M.I. (1990) Justice and the Politics of Difference, Princeton University Press, Princeton

Young, M.I. (2000) Inclusion and Democracy, Oxford University Press, New York 